\title{
Influence of Concomitant Infusion of Thymidine and Inosine on Methotrexate Activity in Normal and P388-bearing Mice*
}

\author{
MARTIN P. UITENDAAL, † JAN H. SCHORNAGEL,§\| ALBERT LEYVA \ and HERBERT M. \\ PINEDO १ ** \\ †Section of Experimental Chemotherapy, Netherlands Cancer Institute, Amsterdam, The Netherlands, \\ $\S$ Department of Internal Medicine, State University Hospital, Utrecht, The Netherlands and 9 Department of \\ Oncology, Free University Hospital, Amsterdam, The Netherlands
}

\begin{abstract}
Combinations of thymidine and inosine (ranging from 0 to $7.5 \mathrm{mg} / \mathrm{hr}$ ) were co-administered during a 72-hr continuous i.v. infusion of $3 \mu \mathrm{g} / \mathrm{hr}$ methotrexate in normal and $P 388$ solid tumor-bearing $D B A / 2$ mice. Methotrexate alone was le thal to all normal mice. Inosine at $1.0-7.5 \mathrm{mg} / \mathrm{hr}$ could reverse toxicity up to $100 \%$ while thymidine at $0.5-7.5 \mathrm{mg} / \mathrm{hr}$ was less effective ( $\leqslant 86 \%$ survival). Combinations of the nucleosides averted toxicity more effectively than either compound alone and in a synergistic manner. From P388 tumor-bearing mice $27 \%$ survived methotrexate and eventually died of tumor. Co-infusion of thymidine or inosine decreased the percentage of toxic deaths and caused an increase in life span of more than $50 \%$ as compared to untreated tumor-bearing mice. However, the diminishing effect on survival with thymidine and inosine doses above $0.5 \mathrm{mg} / \mathrm{hr}$ indicated loss of the antitumor effect of methotrexate. This was also observed with combinations of the nucleosides. The influence of thymidine on the antitumor effect of methotrexate was compared in L1210- and P388-bearing mice (both in ascites) with $13 \mu \mathrm{g} / \mathrm{hr}$ methotrexate for $48 \mathrm{hr}$ and $4 \mathrm{mg} / \mathrm{hr}$ thymidine for $96 \mathrm{hr}$. The increase in life span for 1210 -bearing mice ( 8.6 days, $96 \%)$ was significantly longer than that with P388-bearing mice (6.1 days, $56 \%$ ), probably due to biochemical differences between these tumors. It is concluded that co-administration of inosine and/or thymidine allows the use of methotrexate doses otherwise not tolerated, though with loss of anti-tumor effect. The choice of the tumor model may greatly influence the outcome of in-vivo studies on the modulation of methotrexate action by nucleosides.
\end{abstract}

\section{INTRODUCTION}

IN-VITRO studies have shown that thymidine (dThd) alone or in combination with a purine can reverse the cytotoxicity of methotrexate (MTX) to tumor cell lines [1-3] and mouse myeloid precursor cells [4]. In tumor-bearing mice, allopurinol, which increases purine availability, partly reversed the antitumor activity of MTX

Accepted 29 June 1984

*Supported by the Queen Wilhelmina Fund (project UUKC 77-3).

$\$$ Present address: Department of Pharmacology, University of Limburg, Maastricht, The Netherlands.

\|Recipient of a research fellowship from the Queen Wilhelmina Fund.

**To whom requests for reprints should be addressed. against L1210 but not against P388 [5]. Tattersall et al. [6] showed an improved therapeutic index for MTX in L1210-bearing mice by co-administration of $d$ Thd. Although others confirmed this result with L1210-bearing mice, the reversal of MTX toxicity in normal mice was found to require both dThd and a purine $[7,8]$. It is possible that, in tumor-bearing mice, killed tumor cells provide sufficient amounts of purines [8]. In continuous infusion experiments, Semon and Grindey [9] showed that either dThd or inosine (Ino) could reverse MTX-mediated host toxicity, but that Ino also blocked the antitumor effect.

The aims of the present study were (a) to further our understanding of the interactions of MTX 
with dThd and Ino in normal and tumor-bearing mice using a continuous infusion system, and (b) to determine whether the choice of tumor model in the other studies [7-10] has influenced the results concerning the efficacy of MTX with coadministration of dThd plus purines.

\section{MATERIALS AND METHODS}

Chemicals

MTX was obtained from Pharmachemie BV (Haarlem, The Netherlands), while dThd and Ino were obtained from Sigma Chemical Co. (St. Louis, MO, U.S.A.). Solutions of agents were prepared in $0.65 \% \mathrm{NaCl}$ solution, adjusted to $\mathrm{pH}$ 7.0 , and sterilized by passage through $0.22-\mu \mathrm{m}$ Millipore filters. Powdered RPMI 1640 medium and fetal bovine serum were purchased from Grand Island Biological Co. Europe (Glasgow, U.K.). All other chemicals used were of analytical grade quality and obtained commercially.

\section{Mice}

Female DBA/2 mice (19-21 g) were obtained from IFFA/CREDO, Saint-Germain-sur-l'Arbreste, France. Mice were maintained on standard laboratory diet (RMH-B, Hope Farms BV, Woerden, The Netherlands) and water ad libitum.

\section{Tumors}

P388 leukemia cells, known to be sensitive to MTX [11], were kindly supplied by Dr G. Atassi from the Institute Jules Bordet, Brussels, and were maintaincd in suspcnsion culture as described elsewhere [12]. Cultures were diluted with fresh medium to a density of $10^{5}$ cells $/ \mathrm{ml}$ twice weekly and $24 \mathrm{hr}$ prior to inoculation into mice. In all experiments, $10^{6} \mathrm{P} 388$ cells in $0.5 \mathrm{ml} 0.9 \% \mathrm{NaCl}$ were inoculated s.c. in the cervical region of recipient mice, and drug infusions were initiated $24 \mathrm{hr}$ later. Maintenance of L1210 cells was identical to that for P388. In those experiments in which L1210 and P388 were compared, cells were inoculated i.p. to allow further comparison with studies reported by others $[9,10]$. In each case, survival was calculated from the day of tumor inoculation, termed day 0 .

\section{Infusions}

Drugs were administered by continuous i.v. infusion to unrestrained mice by a technique as essentially described by others $[9,10,13]$. Drugs were infused at a rate of $0.5 \mathrm{ml} / \mathrm{hr}$ for $72 \mathrm{hr}$, unless otherwise indicated. Mice still living on day 30 were scored as survivors.

\section{Analysis of plasma nucleoside levels}

Nucleoside concentrations in plasma samples collected before and during infusion were determined by high-pressure liquid chromatographic methods as described elsewhere [14].

\section{RESULTS}

Reversal of MTX toxicity by nucleosides in normal mice

Continuous i.v. infusion of MTX at a rate of $3 \mu \mathrm{g} / \mathrm{hr}$ for $72 \mathrm{hr}$ resulted in a $100 \%$ kill of nominal mice $(n=14)$. Co-infusion of nucleosides provided dose-dependent protection against MTX toxicity (Fig. 1). Analysis of the data with Fisher's exact probability test [15] indicated that significant $(P<0.05)$ protection from MTX toxicity was provided by dThd at doses of 1,3 and $7.5 \mathrm{mg} / \mathrm{hr}$. At these doses the dThd effect was maximal, resulting in $83 \%$ survival. Ino caused complete reversal of MTX toxicity at a dose of $7.5 \mathrm{mg} / \mathrm{hr}$ $(P<0.05)$. Lower doses $(1.0$ and $3.0 \mathrm{mg} / \mathrm{hr})$ provided only partial protection against MTX toxicity (Fig. 1). In mice treated with $10 \mu \mathrm{g} / \mathrm{hr}$ MTX, dThd had noeffect on MTX toxicity, while Ino at $7.5 \mathrm{mg} / \mathrm{hr}$ produced full reversal (data not shown; ref. [16]).

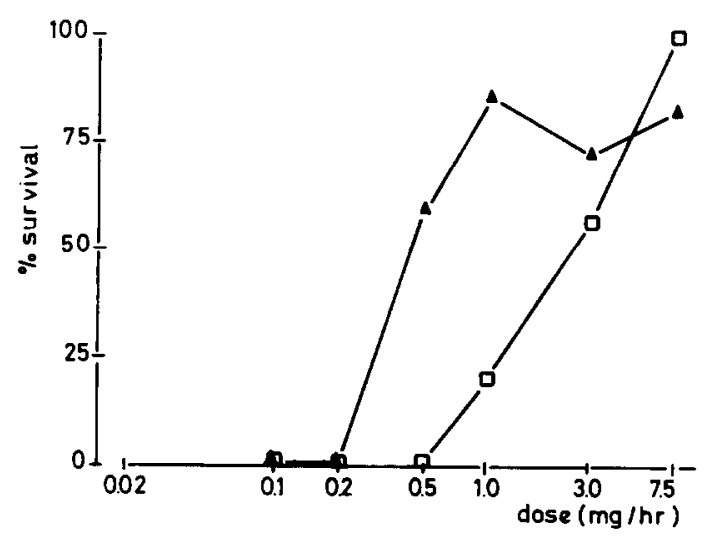

Fig. 1. The relationship between survival and dose of dThd (A) or (口) Ino used for the reversal of $M T X(3 \mu \mathrm{g} / \mathrm{hr})$ toxicity in healthy $D R A / 2$ mice. Fach point represents at least 5 mice.

If the effects of dThd and Ino on MTX toxicity were additive, the expected fraction of mice killed by MTX plus a dThd-Ino combination would be the product of the fraction killed by MTX plus Ino and the fraction killed by MTX plus dThd. Co-infusion of a dThd-Ino combination was more effective in preventing mortality from MTX than either nucleoside alone. Moreover, the survival observed after co-infusion of the dThd-Ino combination was higher than expected on the basis of a merely additive reversal effect (Table 1). Excluding the combinations of $0.2 \mathrm{mg} / \mathrm{hr}$ dThd with 0.5 or $1.0 \mathrm{mg} / \mathrm{hr}$ Ino, all nucleoside combinations tested resulted in $100 \%$ protection against lethal MTX toxicity $(P<0.05$; Fisher's exact test [15]). 
Table 1. Synergism between dThd and Ino in reversal of MTX toxicity

\begin{tabular}{|c|c|c|c|}
\hline \multirow{2}{*}{$\begin{array}{l}\text { dThd dose } \\
\text { (mg/hr) }\end{array}$} & \multirow{2}{*}{$\begin{array}{l}\text { Ino dose } \\
\text { (mg/hr) }\end{array}$} & \multicolumn{2}{|c|}{$\begin{array}{l}\text { Percent survival of mice treated } \\
\text { with MTX and nucleosides* }\end{array}$} \\
\hline & & Calculated $\dagger$ & Measured $\ddagger$ \\
\hline \multirow[t]{4}{*}{0.2} & 0.5 & 0 & 50 \\
\hline & 1.0 & 20 & 43 \\
\hline & 3.0 & 57 & 100 \\
\hline & 7.5 & 100 & 100 \\
\hline \multirow[t]{4}{*}{1.0} & 0.5 & 86 & 100 \\
\hline & 1.0 & 89 & 100 \\
\hline & 3.0 & 94 & 100 \\
\hline & 7.5 & 100 & 100 \\
\hline \multirow[t]{4}{*}{7.5} & 0.5 & 83 & 100 \\
\hline & 1.0 & 86 & 100 \\
\hline & 3.0 & 93 & 100 \\
\hline & 7.5 & 100 & 100 \\
\hline
\end{tabular}

* Mice were given 3 -day infusion with $3 \mu \mathrm{g} / \mathrm{hr}$ MTX and dThd and Ino as indicated.

†Survival was calculated from the product of the percentage kill after rescue with dThd alone and the percentage kill after rescue with Ino alone (i.e. value expected when reversal is additive)

¥The data represent the surviving fraction of groups of at least 5 mice.

Effect of nucleoside infusions on MTX antitumor action against P388 leukemia

Subcutaneous inoculation of $10^{6} \mathrm{P} 388$ leukemia cells resulted in the growth of a large solid tumor with extensive metastatic disease in lungs, liver and spleen, leading to death within 15 days. In contrast with normal mice, not all of the tumorbearing animals were killed by a 3-day infusion of MTX at $3 \mu \mathrm{g} / \mathrm{hr}, 27 \%$ of the animals surviving toxicity and eventually dying of tumor. During the first 6-7 days following MTX infusion, drug toxicity in these animals was apparent from bristling hairs, high back-bones and a $25 \%$ weight loss. This was followed by a gradual increase in weight and improved condition of the mice until the development of large subcutaneous tumors.

Co-administration of $\mathrm{dThd}$ or Ino with MTX provided protection against drug toxicity. The increase in lifespan (ILS) was highest with the lowest nucleoside doses used (Fig. 2, Table 2). All animals surviving beyond day 5 eventually died of tumor. The ILS obtained with MTX plus $\leqslant 1.0 \mathrm{mg} / \mathrm{hr}$ nucleoside was significantly higher than the one obtained with MTX plus 3.0 and $7.5 \mathrm{mg} / \mathrm{hr}$ nucleoside $(P<0.05$, Wilcoxon's test [15]).

Combinations of $\mathrm{d}$ Thd and Ino were also tested for reversal of MTX toxicity in P388-bearing mice. Table 2 shows the relationship between the nucleoside doses used, the median survival time and the percentage of mice protected from MTX toxicity. As observed with co-infusion of single

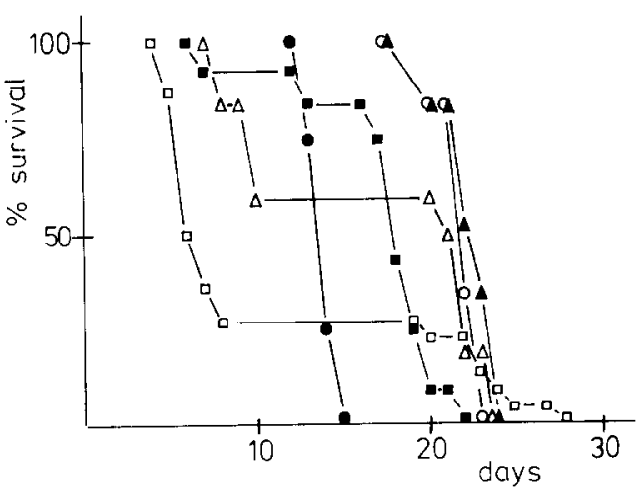

Fig. 2. Survival curves of P388-bearing mice treated with

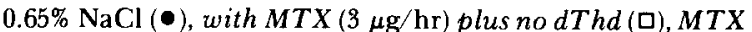
plus $0.2 \mathrm{mg} / \mathrm{hr} d T h d(\Delta), M T X$ plus $0.5 \mathrm{mg} / \mathrm{hr} d T h d(\Delta)$, MTX plus $1.0 \mathrm{mg} / \mathrm{hr} d T h d$ (O) or MTX plus $7.5 \mathrm{mg} / \mathrm{hr} d T h d$

(匹). Each curve represents at least 6 mice.

nucleoside, combinations of the nucleosides resulted in reduced median survival with increasing nucleoside doses.

Comparison between $P 388$ and L1210 in response to MTX plus dThd

To allow comparison with data on L1210 rcported by others $[8,10]$, a parallel experiment was performed with one group of P388-bearing and one group of L1210-bearing DBA/ 2 mice. In this experiment, $10^{6}$ tumor cells were inoculated i.p. Untreated L1210-bearing mice had a Inedian survival of 9 days (range 8-10 days), whereas the median survival of untreated P388-bearing mice was 11 days (range 9-12 days). Both groups were treated simultaneously with MTX at $13 \mu \mathrm{g} / \mathrm{hr}$ ( $16 \mathrm{mg} / \mathrm{kg} /$ day) and with dThd at $4 \mathrm{mg} / \mathrm{hr}$ ( $5 \mathrm{~g} / \mathrm{kg} /$ day) for $48 \mathrm{hr}$, followed by $4 \mathrm{mg} / \mathrm{hr}$ dThd for another $48 \mathrm{hr}$. This was the optimal regimen reported by Semon and Grindey [9] which yielded a $125 \%$ ILS over controls in L1210-bearing DBA/ 2 mice. In our hands, this schedule afforded a $96 \%$ ILS in L1210-bearing mice but only a $56 \%$ ILS in P388-bearing animals. This difference was significant with a $P<0.05$ (generalized $t$ test [15]).

Plasma base and nucleoside levels

Normal DBA/ 2 mice had dThd plasma levels of $2.8 \pm 2.4 \mu \mathrm{M}$ (mean \pm S.D.). Infusion of 1 and $3 \mathrm{mg} / \mathrm{hr}$ dThd yielded mean plasma concentrations of 10 and $25 \mu \mathrm{M}$ respectively. Infusion of $7.5 \mathrm{mg} / \mathrm{hr}$ resulted in dThd plasma levels of over $200 \mu \mathrm{M}$ (Fig. 3). Baseline levels for adenine, hypoxanthine and Ino were below the limit of detection $(<0.5 \mu \mathrm{M})$.

\section{DISCUSSION}

Constant infusions of MTX to DBA/2 mice at a rate of $3 \mu \mathrm{g} / \mathrm{hr}$ for $72 \mathrm{hr}$ yield plasma drug concentrations of $0.1 \mu \mathrm{M}$ [17]. In the present study 
Table 2. Reversal of toxicity of $3 \mu \mathrm{g} / \mathrm{hr} M T \mathrm{X}$ by co-infusion of combinations of $d T h d$ and Ino and effect on antitumor activity of MTX of this co-infusion

\begin{tabular}{|c|c|c|c|c|c|}
\hline \multicolumn{2}{|c|}{$\begin{array}{l}\text { Addition* } \\
\text { (mg/hr) }\end{array}$} & \multirow[b]{2}{*}{$n \dagger$} & \multirow[b]{2}{*}{$\%$ tumor death $\ddagger$} & \multirow{2}{*}{$\begin{array}{c}\text { Median survival§ } \\
\text { (days) }\end{array}$} & \multirow{2}{*}{$\begin{array}{c}\text { Increase in } \\
\text { median survival } \\
(\%)\end{array}$} \\
\hline Ino & dThd & & & & \\
\hline \multirow[t]{5}{*}{0} & 0.0 & 22 & 27 & 6.0 & -57 \\
\hline & 0.2 & 6 & 100 & 22.5 & 61 \\
\hline & 0.5 & 6 & 67 & 21.5 & 54 \\
\hline & 1.0 & 6 & 100 & 22.0 & 57 \\
\hline & 7.5 & 12 & 92 & 18.0 & 29 \\
\hline \multirow[t]{4}{*}{0.5} & 0.0 & 6 & 67 & 21.5 & 54 \\
\hline & 0.2 & 6 & 50 & 15.0 & 7 \\
\hline & 1.0 & 6 & 83 & 20.0 & 43 \\
\hline & 7.5 & 6 & 100 & 18.5 & 32 \\
\hline \multirow[t]{4}{*}{1.0} & 0.0 & 6 & 100 & 21.0 & 50 \\
\hline & 0.2 & 6 & 83 & 22.0 & 57 \\
\hline & 1.0 & 5 & 80 & 20.0 & 43 \\
\hline & 7.5 & 6 & 100 & 19.0 & 36 \\
\hline \multirow[t]{4}{*}{3.0} & 0.0 & 3 & 100 & 19.0 & 36 \\
\hline & 0.2 & 6 & 100 & 19.5 & 39 \\
\hline & 1.0 & 5 & 80 & 18.0 & 29 \\
\hline & 7.5 & 4 & 75 & 16.0 & 14 \\
\hline \multirow[t]{3}{*}{7.5} & 0.0 & 4 & 100 & 18.5 & 32 \\
\hline & 0.2 & 6 & 100 & 16.5 & 18 \\
\hline & 1.0 & 5 & 100 & 17.0 & 21 \\
\hline
\end{tabular}

*All mice were infused for $72 \mathrm{hr}$ with $3 \mu \mathrm{g} / \mathrm{hr}$ MTX plus additions as indicated. $\uparrow$ No. of animals per experiment.

†The percentage of mice dying of tumor after having survived MTX toxicity.

$\S$ Life span from the day that the mice received P388 cells s.c.

|Increase in life span as compared to untreated controls (median survival: 14 days; range: $13-15$ days).

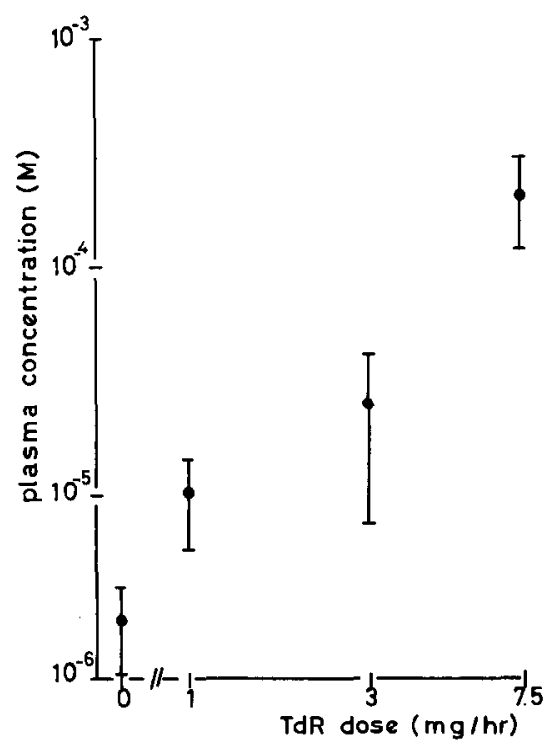

Fig. 3. Plasma dThd concentrations during long-term i.v. infusions in normal $D B A / 2$ mice. The vertical bars indicate the S.E.M. this appears to be lethal to all animals treated. Coinfusion of either dThd or Ino provided substantial protection of mice from MTX toxicity. dThd doses of $1-7.5 \mathrm{mg} / \mathrm{hr}$ provided a maximal protection of up to $83 \%$ of the MTXtreated mice. Ino at $7.5 \mathrm{mg} / \mathrm{hr}$ afforded complete reversal of MTX lethality (Fig. 1, [16]). The limited protective effect of dThd against MTX toxicity in mice as opposed to the complete reversal by Ino was also observed by others $[6,9]$. The rapid clearance of $d$ Thd [16] compared with MTX could account for the lack of complete rescue of mice from MTX toxicity, since in these experiments dThd infusion was not extended beyond the end of MTX infusion.

Another explanation of this difference in protective effect could be our finding that in normal DBA/ 2 mice circulating dThd levels are higher than purine levels. However, others have found relatively high plasma purine concentrations [9]. Differences in handling of blood samples could account for discrepancies in the determination of plasma purine content in view of the rapid turnover of purine nucleotides in erythrocytes [18]. Catabolism of intracellular 
adenine nucleotides at millimolar concentrations followed by leakage of catabolites could lead to substantial increase in plasma purine concentrations [19].

Ino at doses as low as $0.5 \mathrm{mg} / \mathrm{hr}$ enhanced the rescue effect of dThd. Interestingly, combinations of Ino at $0.5-3 \mathrm{mg} / \mathrm{hr}$ with dThd at $0.2 \mathrm{mg} / \mathrm{hr}$ clearly showed synergistic reversal of MTX toxicity (Table l, ref. [16]). Others did note that dThd plus Ino protected normal $[8,9]$ and tumorbearing [7] mice better than either compound alone. However, no conclusive evidence of synergism was provided in these studies. The results of a clinical study of MTX combined with dThd, Ino and allopurinol also suggested that the addition of purine to dThd improves rescue [20].

A recent in-vitro study from our laboratory showing that purines can stimulate the conversion of dThd to dTTP [21] offers a possible explanation for this synergism. Purines, when given in combination with dThd, would not only alleviate the MTX-induced purineless state but also facilitate abolishment of the thymidylate depletion by providing ATP for kinase activities for the formation of dThd nucleotides. This is in agreement with work by others who have demonstrated that MTX can hamper ATP requiring enzyme reactions [22].

Tumor-bearing mice were less sensitive to MTX and required lower doses of nucleosides for complete protection against MTX (Tables 1 and 2). This may be due to an increased availability of circulating salvage metabolites released through lysis of MTX-sensitive tumor cells, as has been suggested previously $[8,23]$.

Mice treated with MTX alone that survived MTX toxicity had an ILS of $69 \%$ (Fig. 2). Coadministration of MTX and nucleosides reduced antitumor effect as well as toxicity of MTX. Treatment with MTX plus nucleosides consistently led to an ILS lower than the $69 \%$ obtained with MTX alone (Table 2). There appeared to be an inverse relationship between the ILS observed and the dose of nucleosides used for reversal of toxicity. No conclusions could be drawn regarding synergistic effects on suppression of antitumor effect.

L1210 cells are known to be less sensitive to MTX than P388 cells [11]. Using an MTX-dThd regimen providing optimal antitumor effect with protection against MTX toxicity $[9,10]$, we found a significantly greater ILS with L1210-bearing mice than with P388-bearing mice. This may be explained by the observation made by Kinahan $e t$ al. [24] that L1210 cells in vitro do not accumulate sufficient dTTP levels in the presence of MTX plus $\mathrm{dThd}$, in contrast to other cclls. In addition, we have demonstrated earlier that MTX toxicity to L1210 cells in vitro is not reversed by low $\mathrm{dThd}$ plus high Ino [12]. Yet the present in-vivo study shows that this nucleoside combination renders MTX inactive against P388 cells. These data suggest that the improved therapeutic effects of MTX plus dThd reported by others [7-10] may be attributed to the differential response of L1210 cells to dThd in the presence of MTX.

Our results with concomitant infusion of MTX and nucleosides in P288-bearing mice are similar to the results from clinical studies with MTX and dThd [25-29] in which the combination was found to have limited antitumor activity, despite the use of minimal doses of dThd which produced only modest increase in plasma dThd concentrations [27-29].

Not only did we confirm that both dThd and Ino are effective agents for reversal of MTX toxicity, but we also demonstrated that these nuclcosides in combination act synergistically. However, the inverse relationship between the antitumor effects of MTX against P388 leukemia cells and the nucleoside doses used precludes substantial improvement of the therapeutic index. The promising results of earlier experimental studies on co-administration of MTX plus nucleosides may have been limited to L1210 leukemic cells.

Acknowledgements-The authors thank Ms. H. Appel, Ms. I. Kraal, Mr. C. Brand and Mr. H. van Heugten for their technical assistance.

\section{REFERENCES}

1. Hakala MT. Prevention of toxicity of amethopterin for sarcoma-180 cells in tissue culture. Science 1957, 126, 255.

2. Borsa J, Whitmore GF. Studies relating to the mode of action of methotrexate. II. Studies on sites of action in L-cells in vitro. Mol Pharmacol 1969, 5, 303-317.

3. Tattersall MHN, Jackson RC, Jackson STM, Harrap KR. Factors determining cell sensitivity to methotrexate: studies of folate and deoxyribonucleoside triphosphate pools in five mammalian cell lines. Eur $J$ Cancer 1974, 10, 819-826.

4. Pinedo HM, Zaharko DS, Bull JM, Chabner BA. The reversal of methotrexate cytotoxicity to mouse bone marrow cells by leucovorin and nucleosides. Cancer Res 1976, 36, 4418-4424.

5. Grindey GB, Moran RG. Effects of allopurinol on the therapeutic efficacy of methotrexate. Cancer Res 1975, 35, 1702-1705. 
6. Tattersall MHN, Brown B, Frei E III. The reversal of methotrexate toxicity by thymidine with maintenance of antitumor effects. Nature 1975, 253, 198-200.

7. Harrap KR, Taylor GA, Browman GP. Enhancement of the therapeutic effectiveness of methotrexate and protection of normal proliferating tissues with purines and pyrimidines. Chem Biol Interact $1977,18,119-128$.

8. Straw JA, Talbot DC, Taylor GA, Harrap KR. Some observations on reversibility of methotrexate toxicity in normal proliferating tissues. $J N C I$ 1977, 58, 91-97.

9. Semon JH, Grindey GB. Potentiation of the antitumor activity of methotrexate by concurrent infusion of thymidine. Cancer Res 1978, 38, 2905-2911.

10. Grindey GB, Semon JH, Pavelic ZP. Modulation versus rescue of antimetabolic toxicity by salvage metabolites administered by continuous infusion. Antibiot Chemother 1978 , 23, 295-304.

11. Goldin A, Venditti JM. The new NCI screen and its implications for clinical evaluation. Recent Results Cancer Res 1980, 70, 5-20.

12. Nederbragt H, Uitendaal MP, van der Grint L, Leyva A, Pinedo HM. Reversal of methotrexate inhibition of colony growth of L1210 leukemia cells in semisolid mediun. Cancer Res 1981, 41, 1193-1198.

13. Paul MA, Dave C. A simple method for long-term drug infusion in mice: evaluation of guanazole as a model (38488). Proc Soc Exp Biol Med 1975, 148, 118-122.

14. Leyva A, Schornagel J, Pinedo HM. High performance liquid chromatography of plasma pyrimidines and purines and its application in cancer chemotherapy. Adv Exp Med Biol 1980, 122B, 380-394.

15. Swinscow TDV. Statistics at Square One. London, The British Medical Association, 1978.

16. Uitendaal MP, Schornagel JH, Leyva A, Pinedo HM. Synergism between purines and thymidine (TdR) in reversal of methotrexate (MTX) toxicity in mice using continuous infusions. Adv Exp Med Biol 1983, 165B, 401-406.

17. Pinedo HM, Zaharko DS, Dedrick RL. Device for constant sc infusion of methotrexate: plasma results in mice. Cancer Treat Rep 1976, 60, 889-893.

18. Mager J, Dvilansky A, Razin A, Wind E, Izak G. Turnover of purine nucleosides in human red blood cells. Israel J Med Sci 1966, 2, 297-301.

19. Schraufstätter I, Born GVR. Dependence of purine loss from human erythrocytes on external pH. Br J Haematol 1981, 49, 349-354.

20. Dady PJ, Taylor GA, Muindi JFR et al. Methotrexate with thymidine, inosine and allopurinol rescue: a phase I clinical study. Cancer Treat Rep 1981, 65 (Suppl. 1), 37-43.

21. Leyva A, Appel H, Pinedo HM. Purine modulation of thymidine activity in L1210 leukemia cells in vitro. Leuk Res 1982, 6, 483-490.

22. Kaminskas E. Inhibition of sugar uptake by methotrexate in cultured Erlich ascites carcinoma cells. Cancer Res 1979, 39, 90-95.

23. Hryniuk WM. The mechanism of action of methotrexate in cultured L5178Y leukemia cells. Cancer Res 1975, 35, 1085-1092.

24. Kinahan JJ, Otten M, Grindey GB. Evaluation of ribonucleoside and deoxyribonucleoside triphosphate pools in cultured leukemia cells during exposure to methotrexate or methotrexate plus thymidinc. Cancer Res 1979, 39, 3531-3539.

25. Ensminger WD, Frei E III. The prevention of methotrexate toxicity by thymidine infusions in humans. Cancer Res 1977, 37, 1857-1863.

26. Howell SB, Ensminger WD, Krishan A, Frei E III. Thymidine rescue of high-dose methotrexate in humans. Cancer Res 1978, 38, 325-330.

27. Howell SB, Herbst K, Boss GR, Frei E III. Thymidine requirements for the rescue of patients treated with high-dose methotrexate. Cancer Res 1980, 40, 1824-1829.

28. Howell SB, Tamerius RK. Achievement of long duration methotrexate exposure with concurrent low dose thymidine protection: influence on methotrexate pharmacokinetics. Eur J Cancer 1980, 16, 1427-1432.

29. Schornagel JH, Leyva A, Pinedo HM. Methotrexate with thymidine protection or rescue in advanced head and neck cancer. A phase II study. Cancer Treat Rep 1984, 68, 543-545. 